ISSN 1810-3030 (Print) 2408-8684 (Online)

\title{
Performances of improved and traditional rice based jhum cultivation in a hill district of Bangladesh
}

\author{
Sujan Mahmud ${ }^{1}$, Md. Rashidul Alam², Mohammed Amin ${ }^{2}$ and Md. Mahmudul Hassan ${ }^{3}$ \\ ${ }^{1}$ Agronomy Division, Bangladesh Agricultural Research Institution, Joydebpur, Gazipur \\ ${ }^{2}$ Regional Agricultural Research Station, Hathazari, Chittagong \\ ${ }^{3}$ Department of Agricultural Extension (DAE)
}

\begin{tabular}{|c|c|}
\hline ARTICLE INFO & Abstract \\
\hline $\begin{array}{l}\text { Article history: } \\
\text { Received: } 11 \text { March } 2018 \\
\text { Accepted: } 06 \text { June } 2018 \\
\end{array}$ & \multirow{3}{*}{$\begin{array}{l}\text { Jhum is a customary farming which is very important for the livelihood of the alpine people of } \\
\text { Bangladesh. Total productivity of the traditional practice of jhum cultivation is very low. The study was } \\
\text { conducted to identify the yield gap between improved and local practices in Bandarban district of } \\
\text { Bangladesh during March to September; } 2017 \text {.The experiment was laid out in randomized complete block } \\
\text { design (RCBD) with ten replications. Improved jhum practice produced the higher yields of rice } \\
(3113 \mathrm{~kg} / \mathrm{ha}) \text {, seed cotton }(456 \mathrm{~kg} / \mathrm{ha}) \text {, sesame }(478 \mathrm{~kg} / \mathrm{ha}) \text { and maize }(627 \mathrm{~kg} / \mathrm{ha}) \text { than traditional local } \\
\text { jhum. Rice Equivalent Yield (REY) was also higher }(40.23 \%) \text { in improved jhum }(6786.8 \mathrm{~kg} / \mathrm{ha}) \text { than local } \\
\text { jhum ( } 4339.8 \mathrm{~kg} / \mathrm{ha}) \text {. Improved jhum's rate of returns }(2.15) \text { was higher than traditional jhum's rate of } \\
\text { returns (1.56). Improved practice in jhum cultivation increased yield and it was economically profitable } \\
\text { over traditional practice. }\end{array}$} \\
\hline $\begin{array}{l}\text { Keywords: } \\
\text { Improved jhum, Rice equivalent } \\
\text { yield, Rate of return }\end{array}$ & \\
\hline & \\
\hline
\end{tabular}

\section{Introduction}

Jhum cultivation is one kind of subsistence farming that produce different types of crops for daily living of the farmers. It is a traditional practice derived from ages of observations to interact with the environment in most harmonious manner. Jhum is a form of customs and rituals of tribal hill people which governs hill agriculture in a cultural and sustainable way where land is cleared by controlled fire, used only for subsistence farming and then natural fallow phase employed long enough to be dominated by woody vegetation (Bhagawati et al., 2015). According to Kerhoff and Sharma (2006) jhum is not synonymous with 'slash-burn agriculture'; in fact it is only a land clearing method. As pointed by Geist and Lambin (2001) jhum or traditional shifting cultivation (swidden-fallow farming) is very much different from shifting cultivation practiced by the migrant settlers and all shifting cultivation is not jhum and all are practiced by different groups of people with wide variation in culture and relationship with ecosystem. Poor productivity is the main problem of jhum cultivation of Bangladesh (UNDP, 2011) and this is mostly because the yield potentiality of local rice varieties is poor. Moreover, farmers do not follow different management practices like weeding, fertilization, pest management etc. Generally average jhum cycle ranges from 12 to 15 years, which allows sufficient vegetation during the interval (Hossain, 2011). But due to scarcity of land, the cycle has shortened to 2-3 years with serious consequence on soil quality (Swapan et al., 2008). To maximize the production of jhum; quality seed of jhum crops have to be available. Bangladesh Rice Research Institute recommended draught tolerant rice variety (BR24, BRRI dhan-27) for upland jhum (BRRI, 2015).
Recently, Bangladesh Agricultural Development Corporation has supplied some draught tolerant rice varieties; narika-1 and narika-10 to Department of Agricultural Extension in CHTs for demonstration in jhum field (DAE, 2016). BARI Hybrid Maize-9 developed by Bangladesh Agricultural Research Institute is an excellent variety for jhum cultivation (BARI, 2016). Several research results revealed that American upland cotton performed better than the hill cotton variety as well as hybrid cotton performed better than open pollinated variety(CDB,2016). Cotton Development Board released 3 open pollinated (OP) high yielding (HYV) American cotton varieties (CB-12, CB-13 and CB-14) while the Rupali-1 is the hybrid American cotton variety released by Supreme Seed Company limited (DAE, 2016). Generally in the traditional jhum cultivation farmers do not use additional fertilizers. Application of N:P:K fertilizer@ 30:30:20 kg/ha gave 40 to $60 \%$ increase in rice yield across the varieties as compared to farmers' practice (no manure or fertilizer) in jhum field (Jayanta et al., 2015). Fertilizer should be applied in line across the slope (Baishya et al., 2015 and SRDI, 2015). In the hilly areas, insect pest and weeds are major threat to decline the yield. Spraying subsequently interval by four times of Ripcord 10EC @1.0 ml/L showed the best efficacy (Talukder and Paul, 2013). The traditional hand weeding in local jhum is not efficient in weed control. Pre-planting non-selective herbicide followed by hand weeding could be best weed management practice for improved jhum cultivation (Shinha et al., 2004). Adoption of line sowing/dibbling across the slope is recommended for reducing soil erosion (Jayanta et al., 2015). So far many previous studies have explored the farming and resource 
management practices in the CHTs of Bangladesh. However, a comprehensive study that deals holistically with yield difference and economy of traditional and improved practice of jhum cultivation is lacking. Under the above circumstances, the study was conducted to find out the performance of improved and local practices of rice based jhum cultivation.

\section{Materials and Methods}

\section{Experimental site and Design}

The experiment was conducted during March to September 2017 at Rameri Para, Bandarban district located in Chittagong Hill Tracts (CHTs) of Bangladesh. Under the activities of the Commission Research Project (Component-III) a jhum hill was selected sited in between $21^{\circ} 55^{\prime} \mathrm{N}$ and $22^{\circ} 22^{\prime} \mathrm{N}$ latitude and $92^{\circ} 08^{\prime} \mathrm{E}$ and $92^{\circ} 20^{\prime} \mathrm{E}$ longitude. The experiment consists of two treatments viz. improved practices of jhum cultivation and traditional practices of jhum cultivation. The experiment was randomized complete block design (RCBD) with ten replications. The distance between block to block and plot to plot was $2.0 \mathrm{~m}$ each. Unit plot size was $(5.0 \times 4.0) \mathrm{m}^{2}$. Site selection and land preparation were done during the month of February. Soil fertility, hill slope, accessibility and distance from village were the main considerations for site selection.

\section{Land Husbandry}

At first, the standing vegetation was slashed and allowed to dry. The dried vegetation was burnt in the month of March, 2017. Rice (local; Cockrow), Cotton (CDB-13), Maize (BARI Hybrid maize-9) and Sesame (local; Sada Ghoissha) were selected for improved practice. Popular local varieties i.e. local jhum rice, local hill cotton, local maize, sesame (ghoissha) were selected for local practice. Chilli and marfa (local varieties) were also sown as local practice of traditional jhum cultivation. The seeds were sown just after the first shower occurred on $15^{\text {th }}$ May, 2017. A narrow hole, about three inches deep was dug with the blunt square end of a tagol (specialized knife), a handful of mixed seeds were placed in the hole. Rice was the higher portion of seed sown by the process. Hill to hill distance for improved practice was $20 \mathrm{~cm}$ and for local practice it was $10 \mathrm{~cm}$. $\mathrm{N}, \mathrm{P}$ and $\mathrm{K}$ fertilizers were applied in the improved jhum @ 30, 30 and 20kg/ha (Jayanta et al., 2015) respectively, whereas no additional nutrients were applied in local practice. All the fertilizers were applied as basal except $\mathrm{N}$ fertilizer. One third of the $\mathrm{N}$ fertilizer applied as basal, and rest of the $\mathrm{N}$ fertilizers were applied by side dressing in the crops hills in early tillering and panicle initiation stage of rice plant. Roundup $5 \mathrm{ml} /$ liter water was applied as pre-planting non-selective herbicide and hand weeding was done before split application of $\mathrm{N}$ fertilizers in improved method. For local jhum weeding was done by using tagol and hand pulling. Ripcord 10EC@ $1.0 \mathrm{ml} / \mathrm{L}$ water was sprayed to control infestation level of major insect pests of jhum. No pesticides were used for local jhum cultivation. Green maize cobs were harvested in late-July. Ripe rice panicles were harvested in September. Cotton and sesame were harvested in September.

\section{Data Collection}

Data on Plant height at harvest $(\mathrm{cm})$, number of total tillershill $^{-1}$, number of effective tillers hill ${ }^{-1}$, length of panicles $(\mathrm{cm})$, number of grains panicle ${ }^{-1}$, number of filled grains panicle ${ }^{-1}$ and 1000 seed weight $(\mathrm{g})$ were collected from ten randomly selected rice plants of each plot. Recorded data were analyzed statistically by using Software (version R i386 3.4.2). Plot yields of rice grain, maize green cob, seed cotton and sesame seed were collected and converted to yield $\mathrm{kg} / \mathrm{ha}$. Total production of the improved system were computed by converting component crop yields (Seed cotton yield, Sesame seed yield, Maize green cob yield) into rice equivalent yield. Similarly total production of the traditional system were computed by converting component crop yields (Seed cotton yield, Sesame seed yield, Maize green cob yield, chilli yield and marfa yield)into rice equivalent yield. Rice equivalent yield was computed by using the following formula : $\mathrm{REY}=\{(\mathrm{Yc} / \mathrm{Pr}) \times \mathrm{Pc}\}+$ Yr. Here, REY = Rice Equivalent Yield, Yc =Yield of the component crop, Yr= Yield of Rice, $\quad$ Pc =Price of the component crop, $\operatorname{Pr}=$ Price of Rice (Thayamini et al., 2010 and Uddin et al., 2009). Difference of REY of improved practice over local jhum practice was calculated and expressed in (\%). Cost of production, gross returns, rate of return of improved and traditional jhum system were calculated. Rate of return over cost was calculated by the formula: Rate of return = Gross Return/ Cost (Esmat et al., 2011).

\section{Results and Discussion}

Yield and yield contributing characters of Rice of the jhum

It is clearly perceptible that grain yield of rice significantly differ among the treatments i.e. improved jhum practice produce more yield (3113 kg/ha) than local jhum yield (2007 kg/ha) (Table 1). Number of effective tillers/hill, number of grains/panicle, number of filled grains/panicles is also significantly high for improved jhum practices than traditional jhum cultivation. According to Chakma and Ando (2008) agronomic management such as method of sowing, fertilization and pest control enhance the yield of a particular variety towards its potential yield. Plant height (cm), total number of tillers/hill, panicle length $(\mathrm{cm})$ and weight of thousand grains (g) were statistically similar between the treatments. This may be due to varietal attributes and genetic characteristics. Shamsuddinet al., (1988) have seen same results in nine amancultivars ofrice in rainfed condition and have concluded that the panicle length $(\mathrm{cm})$ and weight of thousand grains $(\mathrm{g})$ was not significantly influenced by the variety. 
Yield of other component crops of the jhum

Yields of other component crops of the jhum differ significantly for the treatments. Improved jhum practices produced higher seed cotton yield (456 kg/ha), than local jhum (287 kg/ha). Sesame yield significantly increases in improved practice $(478 \mathrm{~kg} / \mathrm{ha})$ than local practices (206 kg/ha) (Table 2). Similar results were observed for maize yield where higher yield was $627 \mathrm{~kg} / \mathrm{ha}$ obtained from improved practice and local practice produce only $393 \mathrm{~kg} / \mathrm{ha}$. Local practice had chili (146 kg/ha) and marfa (600 kg/ha) also. Rice Equivalent Yield (REY) of the two systems was calculated and local practices had shown lower REY than improved jhum practices. REY of the improved jhum was $6786.8 \mathrm{~kg} / \mathrm{ha}$ and local practices produce only $4339.8 \mathrm{~kg} / \mathrm{ha}$ (Table 2). Improved jhum practices produced $40.23 \%$ more rice equivalent yield than local jhum. This huge yield gap was mainly due to the high yielding varieties, advanced and additional agronomic management and better cultivation techniques. Rashid and Chakma (2012) found similar results from suitability study of crop varieties in jhum cultivation. Advanced cultivation techniques would not only increase yield of the shifting cultivation but can also create immense thrust to the socio economy of the tribal people (Miah and Islam, 2007).
Cost and return of the improved and local jhum practice

Cost and return from improved and local jhum cultivation was calculated (Table 3). In Jhum cultivation human labour divided in two parts i.e. family labour and hired labour (Uddin et al., 2010). Family members, neighbors or community members collectively work in the hills from land preparation to harvesting. Family labour generally not paid in money but from products. However total human labour is considered as hired labour at the rate of man-day (8hours). Interest on input cost known as overhead cost (OC) was $12.5 \%$ per year. Full cost of local practice was $78993.75 \mathrm{Tk} / \mathrm{ha}$ where as full cost of the improved practice was $69487.5 \mathrm{Tk} / \mathrm{ha}$. This additional cost in the improved practice was due to labour, fertilizer, pesticides cost. Improved jhum practice produce gross return of 1,69,6705 Tk/ha and net benefit over full cost was $90676.25 \mathrm{Tk} / \mathrm{ha}$. Traditional jhum produce gross return of 1,08,495 Tk/ha and net benefit over full cost was only $39007.5 \mathrm{Tk} / \mathrm{ha}$. In improved jhum cultivation, rate of returns over full cost was 2.15 and traditional jhum cultivations rate of returns over full cost was 1.56. Miah and Islam (2007) showed that improved shifting cultivation produce more benefit and higher rate of return than traditional jhum.

Table 1.Yield and yield contributing characters of rice in improved and local jhum practice

\begin{tabular}{lcccccccc}
\hline \multicolumn{1}{c}{ Entry } & $\begin{array}{c}\text { Plant } \\
\text { height at } \\
\text { harvest } \\
(\mathrm{cm})\end{array}$ & $\begin{array}{c}\text { Number of } \\
\text { total tillers/hill }\end{array}$ & $\begin{array}{c}\text { Number of } \\
\text { effective } \\
\text { tillers/hill }\end{array}$ & $\begin{array}{c}\text { Length of } \\
\text { panicle } \\
(\mathrm{cm})\end{array}$ & $\begin{array}{c}\text { Number of } \\
\text { grains/ } \\
\text { panicle }\end{array}$ & $\begin{array}{c}\text { Number of } \\
\text { filled grains/ } \\
\text { panicle }\end{array}$ & $\begin{array}{c}\text { Weight of } \\
1000 \text { seeds } \\
\text { (g) }\end{array}$ & $\begin{array}{c}\text { Grain } \\
\text { yield } \\
(\mathrm{kg} / \mathrm{ha})\end{array}$ \\
\hline $\begin{array}{l}\text { Improved jhum } \\
\text { practice }\end{array}$ & 141.4 & 10.60 & 7.73 & 21.93 & 153.33 & 134.40 & 26.33 & 3113 \\
Local jhumpractice & 141.0 & 10.27 & 5.29 & 21.63 & 145.67 & 120.87 & 25.67 & 2007 \\
Lsd & 2.76 & 1.52 & 2.24 & 0.86 & 2.07 & 6.67 & 3.79 & 360 \\
CV (\%) & 12.3 & 3.47 & 5.45 & 4.30 & 8.03 & 10.61 & 3.86 & 22.4 \\
Level of significance & $\mathrm{NS}$ & $\mathrm{NS}$ & $*$ & $\mathrm{NS}$ & $*$ & $*$ & NS & $* *$ \\
\hline
\end{tabular}

NS $=$ Non significant, $*=5 \%$ level of significance, ${ }^{* *}=1 \%$ level of significance

Table 2. Yields of different component crops and total REY of improved and local jhum practice

\begin{tabular}{|c|c|c|c|c|c|c|c|c|}
\hline Entry & $\begin{array}{c}\text { Rice grain } \\
\text { yield } \\
\text { (kg/ha) }\end{array}$ & $\begin{array}{c}\text { Seed cotton } \\
\text { yield } \\
(\mathrm{kg} / \mathrm{ha})\end{array}$ & $\begin{array}{c}\text { Sesame } \\
\text { seed yield } \\
\text { (kg/ha) }\end{array}$ & $\begin{array}{l}\text { Maize green } \\
\text { cob yield } \\
\text { (kg/ha) }\end{array}$ & $\begin{array}{l}\text { Chili fruit } \\
\text { yield } \\
\text { (kg/ha) }\end{array}$ & $\begin{array}{c}\text { Marfa fruit } \\
\text { yield } \\
\text { (kg/ha) }\end{array}$ & $\begin{array}{c}\text { Total Rice } \\
\text { Equivalent } \\
\text { Yield (REY) } \\
\text { (kg/ha) } \\
\end{array}$ & $\begin{array}{l}\text { Increase of } \\
\text { REY over } \\
\text { local jhum } \\
\text { practice (\%) }\end{array}$ \\
\hline $\begin{array}{l}\text { Improved jhum } \\
\text { practice }\end{array}$ & 3113 & 456 & 478 & 627 & - & - & 6786.8 & $40.23 \%$ \\
\hline $\begin{array}{l}\text { Local jhum } \\
\text { practice }\end{array}$ & 2007 & 287 & 206 & 393 & 146 & 600 & 4339.8 & - \\
\hline LSD (0.05) & 120.89 & 99.52 & 44.5 & 32.74 & - & - & - & - \\
\hline CV\% & 19.25 & 17.67 & 12.73 & 10.34 & - & - & - & - \\
\hline $\begin{array}{l}\text { Level of } \\
\text { significance }\end{array}$ & * & * & $*$ & * & & & & \\
\hline
\end{tabular}

Rice $=25 \mathrm{tk} / \mathrm{kg}$ Seed cotton $=55 \mathrm{tk} / \mathrm{kg}$, sesame $=120 \mathrm{tk} / \mathrm{kg}$, Maize $=15 \mathrm{tk} / \mathrm{kg}$, Chilli $=20 \mathrm{tk} / \mathrm{kg}$, Marfa $=15 \mathrm{tk} / \mathrm{kg}$ 
Table 3. Cost and Return of Rice Equivalent Yield from Improved and Local Jhum Practice (Tk/ha)

\begin{tabular}{|c|c|c|}
\hline Particulars & Improved Jhum practices & Local Jhum practices \\
\hline A. Human labour & $54000(180)$ & $51000(170)$ \\
\hline a. Family labour + & {$[30000(100)+$} & {$[30000(100)+$} \\
\hline b. Hired labour & $24000(80)]$ & $21000(70)]$ \\
\hline B. Seed & 10100 & 13100 \\
\hline C. Fertilizers & 6450 & 0 \\
\hline D. Pesticides and weedicides & 2000 & 0 \\
\hline E. Miscellaneous cost & 1000 & 1000 \\
\hline F. Interest on overhead cost & 5443.75 & 4387.5 \\
\hline G. Gross cost & 48993.75 & 39487.5 \\
\hline $\begin{array}{l}\text { a. Variable cost } \\
\text { b. Full cost }\end{array}$ & 78993.75 & 69487.5 \\
\hline H. Gross Return & $1,69,670$ & $1,08,495$ \\
\hline I. Net benefit & & \\
\hline a. Over full cost & 90676.25 & 39007.5 \\
\hline b. Over variable cost & 60676.25 & 69007.5 \\
\hline J. Rate of return & & \\
\hline a. Over full cost & 2.15 & 1.56 \\
\hline b. Over variable cost & 3.46 & 2.74 \\
\hline
\end{tabular}

Wage rate (man-day 8 hours) =300 Tk/day/labour, Urea=16 Tk/kg, TSP=22 Tk/kg, MOP=15Tk/kg, Roundup=600 Tk/L, Ripcord=500 Tk/L, OC= overhead cost.

\section{Conclusion}

From the experiment it can be concluded that improved jhum system is better than that of local jhum system. The gap between yield and potential yield of the traditional jhum system can be mitigated by advanced techniques of cultivation. Upgraded production package could be beneficial for increasing yield and thriving economic solvency of the jhumiya people.

\section{Acknowledgement}

The authors are thankful to Commissioned Research Project (CRP-1 Hill agriculture) entitled "Harnessing the Potential of Hill Agriculture: Enhancing Crop Production through Sustainable Management of Natural Resources", funded by Krishi Gobeshona Foundation (KGF).

\section{References}

BARI (Bangladesh Agricultural Research Institute). 2016. Annual Research Report: Agronomy, Soil Science, Plant Protection, PGRC. Hill Agricultural Research Station, Khagrachhari. Bangladesh. pp. 1-4.

Baishya, L.K., Ansari, M.A., Singh, R., Menthoibi, A. and Prakash, N. 2015. Effect of micronutrients and soil amendments on enhancing productivity and quality of rice in acid soils of North-Eastern Hill Region of India. A compendium of seminar papers on 'Sustaining Hill Agriculture in Changing Climate'. Indian Association of Hill Farming, ICAR Research Complex for NEH Region, Meghalaya, Umiam-793103, India. Millennium Graphics, Ambikagirinagar, R.G. Baruah Road, Guwahati-781024, India. pp.133.

Bhagawati, K., Bhagawati, G., Das, R., Bhagawati, R. and Ngachan, S.V. 2015.The Structure of Jhum (Traditional Shifting Cultivation System): Prospect or Threat to Climate. Sci. Press Ltd., Switzerland. International Letters of Natural Sciences. 46:16-30.

BRRI (Bangladesh Rice Research Institute). 2015. BRRI Annual Report. Bangladesh Rice Res. Inst. Gazipur 1701, Bangladesh. pp. 4-14.
CDB (Cotton Development Board). 2016. Annual Report: Cotton Research Centre, Balaghata, Bandarban, Bangladesh. pp. 2-6.

Chakma, S.S. and Ando, K.2008.Jhum cultivation in Khagrachari hill district of Bangladesh- a subsistence farming practices in ethnic minorities. J. Agrofor. Environ. 2 (2): 1-8.

DAE (Department of Agricultural Extension). 2016. Ongoing agriculture extension activities, Additional Directors office, Chittagong Hill Tracts. Ministry of Agriculture. Government of the People's Republic of Bangladesh. pp. 5-6.

Esmat, B. A., Islam, M.N, Alam. Q.M and Hossain, S.M.B. 2011. Profitability of some BARI released crop varieties in some locations of Bangladesh. Bangladesh J. Agril. Res.,36(1): $111-122$.

Geist, H.J. and Lambin, E.F. 2001. What Drives Tropical Deforestation? A meta-analysis of proximate and underlying causes of deforestation based on subnational case study evidence. Report Series \# 4. LUCC International Project Office, Univ. of Louvain, Dept. of Geography.Ciaco Print shop, Grand place 45, 1348 Louvain-la-Neuve, Belgium.pp.85-89.

Hossain, M.A.2011.An overview on shifting cultivation with reference to Bangladesh.Sci. Res. Essays. 6(31):6509-6514.

Jayanta, L., Das, A., Ramkrushna, G. I., Roy, A., Verma, B., Panwar, S. P. and Ngachan, S.V 2015. Sustainable rice production in shifting cultivation: a case study. A compendium of seminar papers on 'Sustaining Hill Agriculture in Changing Climate'.Indian Association of Hill Farming, ICAR Research Complex for NEH Region, Meghalaya, Umiam793103, India. Millennium Graphics, Ambikagirinagar, R.G. Baruah Road, Guwahati-781024, India. pp.184.

Kerkhoff, E. and Sharma,E. 2006. Debating Shifting Cultivation in the Eastern Himalayas: Farmers' Innovations as Lessons for Policy, ICIMOD, Kathmandu, Nepal. pp. 92.

Miah, M.A. and Islam, S.M. 2007. Shifting Cultivation and its Alternatives in Bangladesh: Productivity, Risk and Discount Rates. Working Paper \# 24-07. South Asian Network for Development and Environmental Economics (SANDEE), Kathmandu, Nepal. pp. 5-9.

Rashid, H. and Chakma, P.K.2012. Suitability of rice varieties with other crops and exploration of better managements practices in jhum field. Report on Jhum research results, Rangamati Hill District Council, Rangamati. pp. 6-23. 
Shamsuddin, A.M., Islam, M.A. and Hossain, A. 1988. Comparative study on the yield and agronomic characters of nine Aman cultivars of rice in rain fed condition. Bangladesh J.Agril.Sci.15 (1) 121-124.

Sinha, B., Dey, S. and Kalita, J. 2004. Traditional Pest Management practices of the communities in upland areas of North East India. Conference Paper. National Symposium on Green Pesticides for Insect Pest Management. Entomol. Res. Inst., Chennai, India.pp.11-12.

SRDI (Soil Resource Development Institute). 2015. Guide book of land and soil resource utilization of Chittagong Hill District. Ministry of Agriculture. Government of the People’s Republic of Bangladesh.pp.1-4.

Swapan, C.S., Kazuo, A. and Muhammad, S. 2008. Jhum Cultivation in Khagrachari Hill District of Bangladesh-Effect of Fallow Period and Farming Experience on its Productivity. FORTROP II: Tropical Forestry Change in a Changing World. Kasetsart University, Bangkok, Thailand. International long term ecological research.4:157-173.

Talukder, K. and Paul, T.K. 2013. Report on agricultural development strategy for Rangamati. Agriculture \&Food Security
Project, Rangamati Hill District Council, Rangamati. $\quad$ pp. 15-19.

Thayamini, H., Seran and Brintha, I. 2010. Review on Maize Based Intercropping. J. Agron. 9(3):135-145.

Uddin, M.J., Hassan, K.M. and Miah, M.M. 2010. Identifying livelihood patterns of ethnic minorities and their coping strategies different vulnerabilities situation in Chittagong hill tracts region, Bangladesh. Final report, CF\#7/08, National Food Policy Capacity Strengthening Programme (NFPCSP, FAO). pp.19-20.

Uddin, M.J., Quayyum, M.A. and Salahuddin, K.M. 2009. Intercropping of hybrid maize with short duration vegetables at hill valleys of Bandarban. Bangladesh $J$. Agril.Res. 34(1): 51-57.

UNDP (United Nations Development Program)2011. Annual report: Promotion of development and confidence building in the Chittagong Hill Tracts, Chittagong Hill Tracts Development Fund (CHTDF). UN office, Sher-eBanglanagar, Dhaka1207, Bangladesh.pp.3-4. 